\title{
Tumor-like myxoid change in decidualized scar endometriosis of pregnancy: a case report and review of literature
}

\section{Gebeliğin desidualize skar endometriyozisinde görülen tümör-benzeri miksoid değişiklik: Olgu sunumu ve literatürün gözden geçirilmesi}

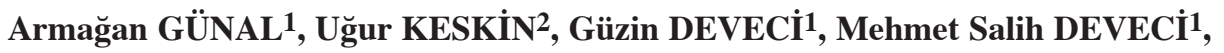 \\ Müfit Cemal YENEN², Murat DEDE² \\ Gülhane Askeri Tıp Akademisi, Patoloji ${ }^{1}$, Kadın Hastalıkları ve Doğum² Anabilim Dalları, ANKARA
}

\begin{abstract}
A case of cesarean scar endometriosis with myxoid change and decidualization in a 24 year-old pregnant is presented. Patient in the second trimester complained of mass in the scar tissue of previous cesarean section. At 40th week of gestation, pregnancy was terminated and subcutaneous mass was removed. Microscopic examination revealed a lesion with lobular pattern and prominent myxoid change in the stroma. Each lobule was containing dilated cystic spaces resembling lymphatic vessels. Also signet-ring like vacuolated cells were present in myxoid stroma. The diagnosis was decidualized scar endometriosis with myxoid change. However, histological features of the lesion may cause diagnostic confusion with benign or malignant tumors such as myxoma, myxoid sarcomas and mucinous adenocarcinoma. Immunohistochemical study and thus recognizing cellular characteristics could help to prevent this misinterpretation.
\end{abstract}

Key words: Scar endometriosis, decidualization, myxoid change

\section{ÖZET}

\begin{abstract}
Yirmi dört yaşındaki gebe kadının eski sezeryan kesi yerindeki desidualize skar endometriyozisinde saptanan miksoid değişiklik bir olgu olarak sunulmaktadır. Gebeliğinin ikinci trimesterindeki hasta eski sezeryan kesi yeri skar dokusunda oluşan kitle şikayeti ile başvurdu. Kırkıncı haftada gebelik sonlandırıldı ve subkutanöz kitle çıkarıldı. Mikroskopik incelemede stromasında belirgin miksoid değişiklik görülen lobüler paterndeki lezyon görüldü. Her lobül lenfatik damarlara benzeyen dilate kistik boşluklar içeriyordu. Ayrıca stromada taşlı yüzük benzeri vakuole stoplazmalı hücreler de mevcuttu. Tanı, miksoid değişiklik gösteren desidualize skar endometriyozisi olarak belirlendi. Bununla birlikte, lezyonun histolojik özellikleri miksom, miksoid sarkom, müsinöz adenokarsinom gibi benign ve malign tümörlerle tanı karışıklığına yol açabilir. Immünhistokimyasal inceleme ve hücresel morfolojik özelliklerin tanınması bu yanlış yorumlamayı önlemeye yardımcı olabilir.
\end{abstract}

Anahtar sözcükler: Skar endometriyozisi, desidualizasyon, miksoid değişiklik

\section{INTRODUCTION}

Endometriosis is the term used to describe the presence of endometrial glands and stroma in abnormal locations outside the uterus. It can also arise in scar tissues either associated

Received: 12.08 .2008

Accepted: 13.10 .2008

Corresponding Author: Dr. Armağan Günal, Gülhane Askeri Tıp Akademisi, Patoloji Anabilim Dalı, 06018 Etlik, Ankara with previous abdominal surgery such as cesarean section or episiotomy (1). Various histologic changes could be seen in endometriosis such as fibrosis, glandular hyperplasia or metaplasia, decidual changes, atrophy, and calcification (2). Myxoid change is a rare type which might be confused with epithelial or mesenchymal neoplasms both clinically and morphologically.

A case of decidualized scar endometriosis with pronounced myxoid change including 
signet ring-like cells is presented and discussed in the light of relevant literature.

\section{CASE REPORT}

A 24-year-old patient noticed a subcutaneous mass during the second trimester of pregnancy beneath her previous cesarean section incision scar. Due to ongoing pregnancy surgical excision was not performed. Follow-up showed no increase in size. The subcutaneous mass, which was not adherent to fascia was removed at 40th week of gestation during cesarean section.

Macroscopically $3 \times 2 \times 2 \mathrm{~cm}$ circumscribed gray-white lesion with gelatinous areas was noted (Figure 1). Microscopically lobular pattern separated by fibrous septa was observed. Each lobule contained cystic spaces (Figure 2A) lined with single layer of atrophic cells with no cytoplasm, resembling endothelium of lymphatic vessels. Loosely cohesive, vacuolated signet ring-like cells embedded in myxoid stroma were

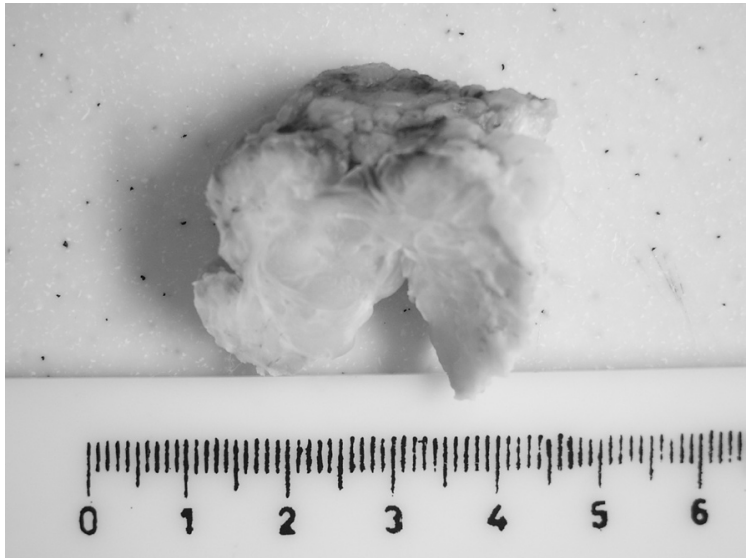

Figure 1. Macroscopic view of the gray-white gelatinous mass.

also noted (Figure 2B). However, no mitotic activity or nuclear atypia was seen.

Histochemically, alcian blue test was positive in myxoid areas and vacuolated cells but PAS staining was negative. Immunohistochemically; vimentin $(1 / 100, V 9$, Neomarkers, Fremont, CA, USA), S-100 (1/100, 4C4.9, Neomarkers, Fremont, CA, USA), keratin (1/100, AE1/ AE3, Neomarkers, Fremont, CA, USA) and CD

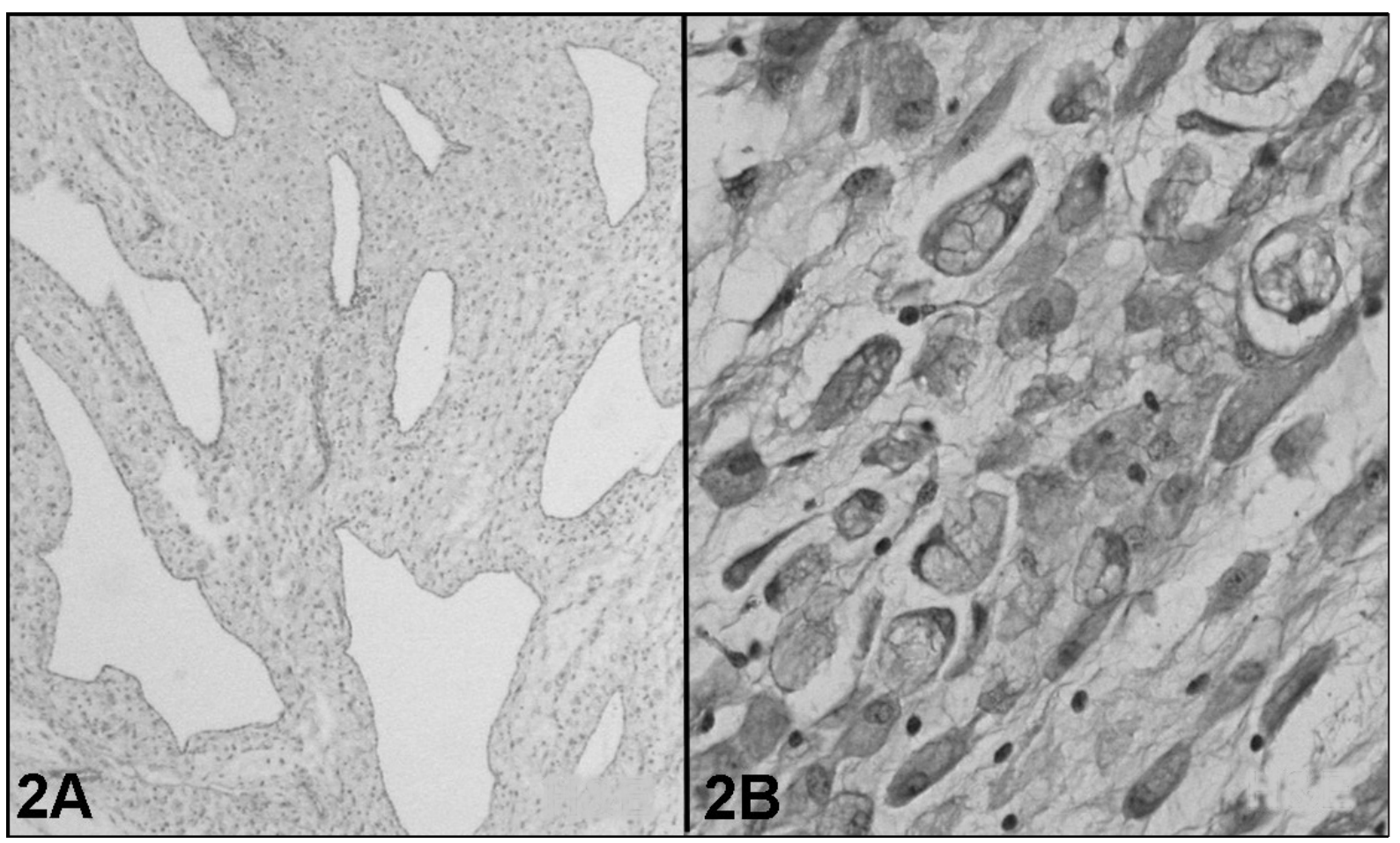

Figure 2. (A) Cystic spaces resembling lymphatic vessels (HE,x40) and (B) vacuolated signet ring-like cells of the decidualized myxoid stroma (HE,x200) are seen. 


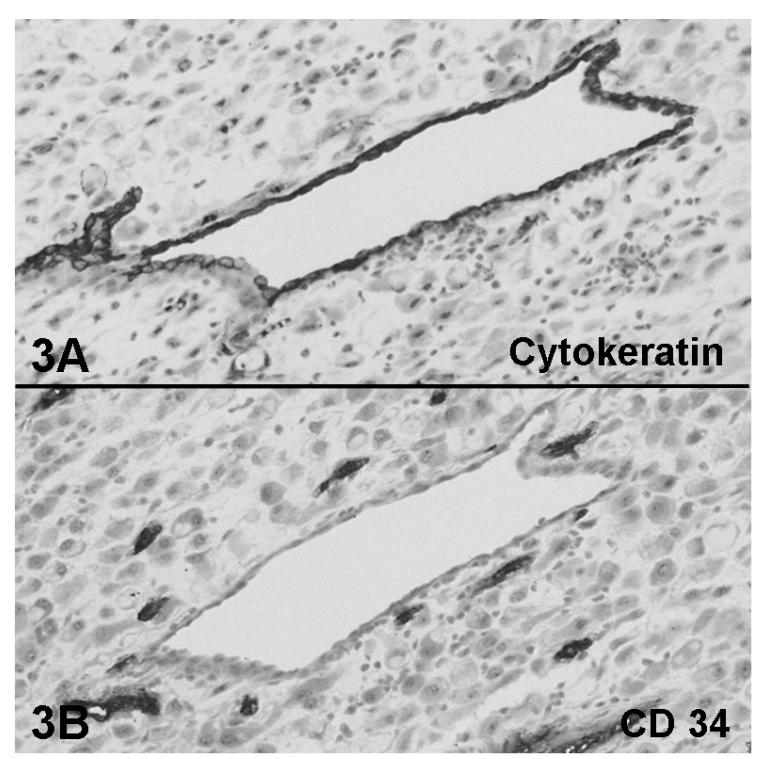

Figure 3. (A) Keratin positivity for the lining cells of the cystic spaces (endometrial glands), but negativity in vacuolated (decidual) stromal cells and (B) CD 34 negativity for the lining cells of the cystic spaces (endometrial glands) $(\mathbf{x 1 0 0})$.

34 (1/100, QBEnd, Neomarkers, Fremont, CA, USA), CD 10 (1/30, Ab-2 clone 56C6, Neomarkers, Fremont, CA, USA) stainings were performed. Vimentin was strongly positive in vacuolated signet ring-like cells (decidual cells), CD10 was also focally positive in the cell membranes of the decidualized cells, but keratin, S-100 and CD 34 tests were negative. Atrophic lining cells of cystic spaces were positive for keratin (Figure 3A) and negative for CD 34 (Figure 3B). The histopathological diagnosis was decidualized scar endometriosis with myxoid change.

\section{DISCUSSION}

Endometriosis is a common phenomenon; defined as the presence at functioning endometrial tissues outside the uterine corpus. Scar endometriosis is a rare entity commonly seen after surgery. It may also arise in noncicatrized tissue in the umblical and inguinal regions (1). In most cases the histological features of endometriosis are not problematic as for diagnosis. However, fibrosis, glandular hyperplasia or metaplasia, ossification and calcification are known to be secondary to degenerative changes which can also be seen along with endometriosis (2). Myxoid change in the stroma is a rare finding which can be confused easily with malignancies; e.g. metastatic adenocarcinoma, pseudomyxoma peritonei of a mucinous tumor, myxoma, myxoid liposarcoma and myxoid variant of malignant fibrous histiocytoma.

There are few reported cases with "myxoid change endometriosis" in the literature. Three of them were seen in nonpregnant $(2,4,6)$ and two in pregnant patients $(3,5)$. In the present case patient was pregnant and had a history of cesarean section (Table 1).

Myxoid change in endometriosis could be misinterpreted as a neoplasm, clinically and histologically, especially during frozen section.

Hameed et al. (6) and Clement et al. (2) reported endometriosis with myxoid change in a nonpregnant patient, whose frozen section examination caused confusion with mucinous adenocarcinoma and pseudomyxoma peritonei.

Table 1. Clinico-pathological features of previous reported cases.

\begin{tabular}{|c|c|c|c|c|c|}
\hline & Pregnancy & Age & Localisation & Diameters & Diagnosis \\
\hline 1 Clement et al. (2) & - & 46 & Cervix of uterus & $2 \mathrm{~cm}$ & $\begin{array}{l}\text { Adenocarcinoma-pseudomyxoma } \\
\text { peritonei (frozen section) }\end{array}$ \\
\hline 2 Hameed et al. (6) & - & 51 & Umblical hernia area & Wall of hernia sac (diffusely) & $\begin{array}{l}\text { Adenocarcinoma-pseudomyxoma } \\
\text { peritonei (clinic-frozen section) }\end{array}$ \\
\hline 3 Ying et al. (4) & - & 24 & Abdominal C.S. scar & $4 \mathrm{~cm}$ & Myxoid change in endometriosis \\
\hline 4 McCluggage and Kirk (5) & + & 25 & Groin & $6 \mathrm{~cm}$ & Myxoid change in endometriosis \\
\hline 5 Nogales et al. (3) & + & 25 & Abdominal C.S. scar & $17 \times 6 \mathrm{~cm}$ (ulcerated area) & Myxoid change in endometriosis \\
\hline 6 Presented case & + & 24 & Abdominal C.S. scar & $3 \mathrm{~cm}$ & $\begin{array}{l}\text { Decidualized scar endometriosis } \\
\text { with myxoid change }\end{array}$ \\
\hline
\end{tabular}

C.S: cesarean section 
Ying et al. (4) also described myxoid change associated with endometriosis in a nonpregnant patient who had cesarean section one year ago. Histological findings showed foci of large irregular endometrial glands embedded in myxoid stroma and acellular mucin pools, presenting as a pseudomalignancy.

Ying et al. (4) hypothesized these myxoid changes as a cyclic, hormone driven, predecidual stroma altered during the menstrual cycle. In case of pregnancy some authors related the changes as a form of altered decidua. When associated with a scar, the lesion arises as a result of iatrogenic mechanical implantation.

Mc Cluggage (5) and Nogales (3) reported cases of endometriosis with myxoid change in pregnant patients. The presenting features in our case were similar to the findings of Nogales et al. (3), because both of these patients developed a mass at the scar tissue of cesarean section. In case of Cluggage (5) although patient was pregnant, the site of endometriosis was unusually localized in the groin. Histological findings were similar being abundant myxoid change with marked decidualization and calcification. Suspicion for malignancies like soft tissue sarcoma, mucinous adenocarcinoma and variety of benign and malignant mesenchymal myxoid lesions were taken into consideration. The authors pointed out that myxoid change in this case may be degenerative in nature and related to pregnancy. In our case, there was no calcification.

Differential diagnosis is particulary important during intraoperative consultation. Myxoid stroma, vacuolated cells could cause misinterpretation (2). In this situation, recognizing the absence of characteristic signs of malignancy such as nuclear atypia and mitosis prevents overdiagnosis. Histochemical and immunohistochemical studies can be helpful for routine interpretation. In signet ring cell carcinoma, PAS strongly stains the cytoplasmic vacuoles whereas the decidual cells are PASnegative. Immunohistochemically, decidual cells are strongly vimentin positive while mucinous carcinoma cells are not. Also keratin stains negatively in decidua but positively in carcinoma. In our case vimentin was strongly positive in vacuolated (decidual) cells. CD10, as an important marker for endometrial stroma, was also positive in the cell membranes of the decidualized cells, but keratin expression was negative.

As a result; although the histologic diagnosis of endometriosis is usually easy, diagnostic problems can occur as a result of alterations or absence of glandular or stromal components, or when secondary changes are present, especially myxoid change which is rarely seen and not very well known by pathologists. It can be confused with neoplasm clinically and histologically. A special care should be taken while taking patients' obstetrical and surgical history and examining their pathology specimens. Also immunohistochemical and conventional histochemical tests may also help in differential diagnosis.

\section{REFERENCES}

1. Brenner C, Wohlgemuth S. Scar endometriosis. Surg Gynecol Obstet 1990;170:538-540.

2. Clement PB, Ganai CO, Young RH, Scully RE. Endometriosis with myxoid change. A case simulating pseudomyxoma peritonei. Am J Surg Pathol 1994;18:849-853.

3. Nogales FF, Martin F, Linares J, Naranjo R, Concha A. Myxoid Change in decidualized scar endometiosis mimicking malignancy. J Cutan Pathol 1993;20:8791.

4. Ying AJ, Copeland LJ, Hameed A. Myxoid change in nondecidualized cutaneous endometriosis resembling malignancy. Gynecol Oncol 1998;68:301-303.

5. McCluggage WG, Kirk SJ. Pregnancy associated endometriosis with pronounced stromal myxoid change. J Clin Pathol 2000;53:241-242.

6. Hameed A, Jafri N, Copeland LJ, O'Toole RV. Endometriosis with myxoid change simulating mucinous adenocarcinoma and pseudomyxoma peritonei. Gynecol Oncol 1996;62:317-319. 